\title{
PANDANGAN ESKATOLOGI DALAM DANIEL 12:1-13
}

\author{
Robi Prianto
}

\begin{abstract}
ABSTRAK
Masalah mengenai akhir zaman dalam kitab Daniel sering menjadi perdebatan yang sengit di kalangan kekristenan. Padahal masalah akhir zaman dalam kitab Daniel, secara khusus Daniel 12:1-3, dapat diselesaikan dengan mempelajari kitab Daniel secara teliti dan seksama. Akhir zaman tidak bisa di kira-kira ataupun diketahui oleh siapa pun. Seperti yang dinyatakan dalam Injil Matius 24:36, "tetapi tentang hari dan saat itu, tidak seorangpun yang tahu, malaikat-malaikat di surga tidak, dan anak pun tidak, hanya bapak sendiri." Akan tetapi, sebagian kalangan yang mempercayai penafsiran harfiah terhadap alkitab menegaskan bahwa ramalan mengenai tanggal-tanggal atau waktu adalah sia-sia dan sebagian penulis lainnya percaya bahwa Yesus meramalkan tanda-tanda yang akan menunjukan bahwa akhir zaman sudah dekat, namun mengenai tanggal kejadiannya bahwa zaman akhir akan datang seperti pencuri dimalam hari.
\end{abstract}

Frasa kunci: Akhir zaman, Daniel 12, Makna Teologis, Kehidupan Umat.

\section{PENDAHULUAN}

Dewasa ini, banyak bermunculan fenomena mengenai akhir zaman. Bahkan di dalam kekristenan sendiri, setiap denominasi memiliki pandangan yang berbeda-beda mengenai akhir zaman. Hal tersebut berimbas pada bermunculannya aliran-aliran yang menitikberatkan pengajarannya pada akhir zaman, bahkan mereka dengan berani mengatakan kapan akhir zaman akan tiba, seperti kaum adventis dan pondok nabi.

Contohnya, kaum Adventis, semenjak berdirinya aliran ini sudah beberapa kali meramalkan mengenai akhir zaman, akan tetapi tidak pernah terjadi. Kaum Adventis mengharapkan bahwa kedatangan Kristus yang kedua kalinya, akan terjadi dalam bentuk suatu peristiwa bencana hebat, 
telah muncul sepanjang era kekristenan; khususnya pada masa Reformasi Protestan dan sesudahnya. Emanuel Swedenborg menganggap kedatangan Kristus yang kedua kali secara simbolik, sudah terjadi pada tahun 1757. Pada abad ke 19 tokoh Adventis William Miller dan para pengikutnya menetapkan waktu kedatangan kembali Kristus dengan perhitunganperhitungan kalender yang didasarkan pada tulisan-tulisan apokaliptik di alkitab. Miller pada waktu itu menyimpulkan kedatangan Kristus pada tahun 1843 atau selambat-lambat 1844. Ada juga yang memprediksi kedatangan Yesus dengan melihat bencana moral, gejala alam, peperangan dan dengan demikian mereka percaya bahwa penghakiman Allah terhadap dunia yang dilanda konflik dan korup ini sudah makin dekat. ${ }^{1}$

Selain itu ada juga Pondok Nabi yang dipimpin oleh Mangapin Sibuea yang meramalkan akhir zaman atau kiamat akan terjadi pada tanggal 10 November 2003, hasilnya bukan kiamat yang terjadi tetapi Mangapin Sibuea sendiri yang ditangkap oleh polisi karena sudah mengajarkan ajaran yang sesat. ${ }^{2}$ Selain kaum Adventis dan Pondok Nabi, masih banyak aliran yang

Jan S. Aritonang, Berbagai Aliran Di Sekitar Gereja (BPK Gunung Mulia, Jakarta 1996), 290.296

${ }^{2}$ Salah seorang jemaat yang bernama NN, 21 tahun, salah satu anggota jemaat Sibuea, tak peduli dengan banyaknya tanggapan sinis dan nyinyir terhadap kelompoknya. "Bukankah Tuhan Yesus juga pernah dihina dan dicaci. Ikut Tuhan Yesus harus menderita, bukan enak-enak saja," ujarnya, tenang. Begitu yakinnya dengan kepercayaan itu, mahasiswi Fakultas Ekonomi, Universitas Kristen, Kupang, ini rela meninggalkan bangku kuliah dan pergi ke Bandung, sejak Maret 2003. NN mengaku mendengar suara Tuhan pertama kali saat kuliah 2001. Suara-suara itu antara lain meminta dirinya untuk pergi ke Baleendah. NN adalah satu dari sekitar 300 pengikut sekte Sibuea. Mereka dievakuasi polisi dari 'Pondok nabi' markas mereka di Jalan Siliwangi, Baleendah, Kabupaten Bandung, Jawa Barat, ke Gereja Bethel Tabernakel, Senin (10/11/2003).Selain NN yang sudah berada di asrama 'Pondok Nabi,' ada juga RY asal Ambon, dan HMN asal Medan. Bersama sekitar 300 orang jemaat yang lain, mereka berkumpul dan melakukan ritual, seperti menyanyi, menari, dan berpuasa, ada yang 3 hari 3 malam tak makan, ada juga yang 7 hari 7 malam tak makan. Semua itu dilakukan untuk bersiap-siap menjemput Kiamat, 10 November 2003. Sebelum polisi mengevakuasi paksa, RY mengaku sempat mulai diangkat ke langit. Tapi, semuanya gagal karena ada gangguan dari pihak luar. "Saat itu, 
serupa dengan mereka, bahkan ada yang lebih radikal. Dari contoh-contoh kasus diatas, maka muncul suatu pertanyaan berkaitan dengan akhir zaman, yaitu mengapa begitu banyak orang Kristen sangat antusias mengenai akhir zaman? Bagamanakah pandangan alkitab, secara khusus kitab Daniel 12:113 mengenai akhir zaman.

\section{DEFINISI ESKATOLOGI}

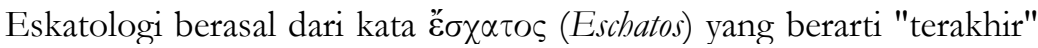
dan logi yang berarti "studi tentang". Jadi, eskatologi adalah ilmu yang mempelajari mengenai akhir zaman. Aspek esensial dari eskatologi adalah fakta pengungkapan sejumlah peristiwa yang akan terjadi di masa yang akan datang melalui nubuat pada masa yang lampau. Sebab itu nubuat alkitab menjadi fokus utama dalam penyelidikan dan pembahasan mengenai eskatologi. Dalam bukunya Subekti mendefinisikan akhir zaman sebagai zaman yang gelap, dan jika ingin menjadi anak terang, maka perlulah memiliki surga nubuat sebagai perelngkapan senjata terang. ${ }^{3}$ Penggenapan nubuat surga Allah pada akhir zaman merupakan dasar kekuatan bagi orang Kristen untuk mempercayai surga nubuat yang akan digenapi.

Jadi Eskatologi adalah sebuah ilmu yang mempelajari suatu masa yang akan terjadi di masa depan, yaitu suatu zaman yang penuh dengan kesusahan, yang di karenakan zaman tersebut akan datang seorang mesias atau penyelamat. Eskatologi tidak hanya dipercayai oleh agama Kristen saja, tetapi eskatologi juga ada di dalam agama Islam dan Yudaisme. Masa-masa atau zaman mesianik tersebut biasa dikenal dengan akhir zaman atau akhir

mulai terasa ada yang masuk ke tubuh saya. Ada perasaan seakan-akan saya mulai diangkat," kata RY, yang bergabung sejak Juli 2003 itu. Bagi ketiga jemaat, Mangapin Sibuea adalah sosok panutan yang menyebar ajaran kebenaran. Tak hanya oleh mereka, tapi juga oleh anggota jemaat yang lain. "Setelah 'Kiamat' Sekte Sibuea Tak Terjadi." Tempo, Rabu, 12 November 2003.

3 Tomotius subekti, Tafsir Daniel, Nubuat Akbir Zaman (Yogyakarta: Andi, 1994), 7. 
dunia, di karenakan pada waktu itu zaman telah tertata menjadi sebuah tatanan dunia yang baru bebas dari penderitaan.

Istilah eskatologi tidak ditemukan dalam dunia Perjanjian Lama (PL). Tetapi hakekat mengenai eskatologi sudah ada, yang dikenal dengan istilah Hari Tuhan. Hari Tuhan diartikan dengan waktu yang sangat lama sekali, suatu musim tertentu di mana peristiwa luar biasa terjadi, seperti kemakmuran, kejayaan, dan bahkan suatu peristiwa yang merugikan yang mendatangkan bencana. ${ }^{4}$ Kepercayaan yang berkembang dalam PL mengenai akhir zaman yaitu mengenai datangnya suatu hari di mana Allah secara dramatis campur tangan melepaskan umat-Nya dari berbagai ketakutan dan penindasan. Biasanya untuk memperingati peristiwa tersebut diadakan perayaan tahunan dengan mengadakan upacara korban, dengan harapan Israel memperoleh kemenangan atas musuhnya.

Kitab Daniel merupakan kitab yang bersifat apokaliptik, artinya penyingkapan. Selain kitab Daniel di dalam PL, ada juga kitab Wahyu dalam Perjanjian Baru (PB) yang bersifat apokaliprtik. Kitab-kitab yang berisfat apokaliptik biasanya berisi mengenai ajaran wahyu, yang sering dicampuradukan dengan ungkapan-ungkapan lain, seperti peringatanperingatan para nabi yang menubuatkan atau yang melihat masa depan, dengan pengalaman-pengalamannya dan bahkan dengan seluruh kehidupannya, seperti yang dijumpai dalam kitab Daniel dan Wahyu.

\section{TAFSIRAN AKHIR ZAMAN DANIEL 12:1-13 MENURUT PARA AHLI}

Di dalam menafsirkan mengenai akhir zaman dari Dan.12:1-13, ternyata banyak pandangan/tafsiran yang berbeda satu dengan yang lainnya. Oleh karena penulis akan mengkelompokannya menjadi dua kubu, yaitu kubu yang menafsirkan akhir zaman dimengerti terjadi saat itu (historis) dan kubu yang menafsirkan akhir zaman merupakan peristiwa yang akan datang (futuris).

${ }^{4}$ William Wilson, Old Testament Word Studies; The International Standard Bible Encyclopaedia vol. II (Grand Rapids: Eerdmans, 1998), 977. 


\section{Kelompok Historis}

Mewakili kelompok historis, penulis mengambil tiga pandangan/tafsiran dari para ahli teologi, di antara:

\section{Alexander A. Di Lella}

:1-4, berisikan penjelasan dari malaikat Tuhan mengenai kesusahan besar yang akan dialami olah orang-orang Israel. "Pada waktu itu Mikhael, pangeran besar, pelindung umat-Mu, akan bangkit. Ini akan menjadi masa kesusahan, seperti tidak pernah terjadi sejak bangsa-bangsa terwujud sampai saat itu. Tetapi pada waktu itu orang-orang Israel akan diselamatkan. Pada ay.2 dikatakan, bahwa banyak dari mereka meninggal akan bangkit dan memperoleh hidup kekal, dan yang sisanya akan mengalami penyiksaan kekal. Namun pada ayat yang ke-3, diterangkan, bahwa orang-orang yang bertindak bijaksana akan bersinar terang seperti cahaya cakrawala; dan orang-orang yang memimpin orang banyak ke kebenaran akan bersinar seperti bintang-bintang selama-lamanya. Dan pada ayat yang ke-4, Daniel disuruh untuk merahasiakan dan menyegelnya, sehingga banyak yang akan murtad, dan kejahatan "akan meningkat." Dalam Dan.12: 5-13, dijelaskan mengenai pemurnian iman dari orang-orang Israel. Pada masa permurnian tersebut orang-orang Israel akan mengalami kengerian atau kekelaman dalam kehidupan mereka, dan hal itu akan berlangsung sesuai dengan waktunya Allah. Adapun penyebutan angka-angka, itu hanya merupakan simbol atau merujuk kepada pemerintahan Antiokhus Efipanes IV. Bagi orang-orang Israel yang bijaksana, maka akan bertahan di dalam masa pemurniaan itu, dan mereka akan mendapatkan kebahagiaan, tetapi mereka yang jahat akan binasa. ${ }^{5}$

Jadi akhir zaman menurut Alexander A. Di Lella adalah bukan merujuk pada masa yang akan datang, tetapi merujuk kepada berakhirnya masa penindasan terhadap orang Israel, dengan ditandai berakhirnya kekuasaan dari Antiokhus IV.

\section{S. M. Siahaan \& Robert M. Paterson}

5Louis Hartman, \& Alexander A. Di Lella. The Anchor Bible, The Book of Daniel (New York: Doubleday \& Company, Inc, 1978), 260-261. 
Menurut Siahaan pasal 12 memilki topik tentang akhir zaman. Mulai dari ay. 1 sampai dengan ay. 4, jelas-jelas memberikan penjelasan tentang akhir zaman pada keterangan pengantar akhir zaman. Ini bisa dibuktikan dengan kata Pada waktu itu, hal tersebut jelas merupakan kelanjutan dari pasal 11 mengenai eskatologi, lalu kata Michael yang menjadi pemimpin dan pelindung Surgawi bagi bangsa Israel, Orang- orang tertidur di dalam debu tanah, akan bangkit pada zaman akhir dan memperoleh hidup kekal serta Orangorang bijaksana, akan dibangkitkan dan akan bercahaya dalam kemuliaan Allah. Namun, ay. 4 merupakan surga Allah yang sulit di mengerti dan banyak ahli- ahli tafsir sering menghubungkan ayat ini dengan Amos 8:12 yang berpendapat "Orang akan berlari ke sana kemari untuk mencari pengetahuan tentang Allah, tetapi tidak akan mendapatkan dan kitab ini berisi semua pengetahuan yang dibutuhkan. Peristiwa-peristiwa bersejarah diriwayatkan dalam bentuk nubuat. Alasan mengapa sejarah ditulis dalam bentuk nubuat sudah di sebut dalam catatan pasal 8, yaitu menekankan peristiwa-peristiwa dalam sejarah terjadi menurut rencana Allah, di tengahtengah peristiwa yang sulit dimengerti oleh manusia. Pada ay. 40 penyusun kitab Daniel pindah dari sejarah dalam bentuk nubuat yang sesungguh, tetapi dalam keterangan berikut tidak dapat disesuaikan dengan fakta-fakta sejarah. Tetapi ada persoalan yang mendesak pada zaman itu tentang respon ayat ini mulai dari Apakah Allah mendampingi umat Israel dalam kesesakan yang dialami? apakah umat Israel akan diselamatkan dari kesesakan? Apakah orang yang setiap yang sudah meninggal mengambil bagian dalam kerajaan Allah pada akhir zaman jawaban dalam ketiga soal menarik hati sebab merupakan perkembangan besar dalam pikiran orang-orang Israel tentang hidup sesudah mati, untunglah penyusun kitab Daniel memberikan jawaban yang lebih memuaskan atas dasar keyakinannya tentang sifat Allah, yaitu Allah adalah Mahakuasa, Mahapengasih, Adil dan Setia. Dengan demikian penyusunan kitab Daniel menjadi saksi tentang pengharapan agung di depan orang-orang Israel. Pada pasal terakhir yakni, pasal 12:5-13 yang merupakan kata penutup, Daniel melihat tampak dua orang orang lain seorang berada di tepi sungai lain dan yang lain di tepi sungai yang sebalah sana dan Daniel melihat serta mendengar perbincangan yang menjurus kepada akhir zaman yang bisa di temukan dalam kitab Daniel bagian terakhir yang merupakan kata penutup dan pada ay. 13, kitab Daniel berakhir dengan suasana tenang. 
Sama seperti semua orang lain, Daniel harus meninggal dunia dan beristrahat dalam kuburnya. ${ }^{6}$

Jadi, akhir zaman menurut Siahaan adalah berbicara mengenai pengharapan orang-orang Israel yang setia dan yakin bahwa Allah akan membebaskan mereka dari penderitaan yang sedang dialami.

\section{Donald Guthrie}

Daniel pasal 9 menceritakan tentang penglihatan mengenai akhir zaman. Akhir zaman yang dikatakan di sini bukanlah menunjuk kepada akhir dari segala-galanya, juga bukan penghakiman terakhir, tapi kepada zaman penderitaan yang akan menimpa Israel. Akhir murka ini yaitu akhir masa murka yang akan menimpa umat Allah. Lewat doa Daniel mengakui kesalahan umat Israel dan dalam pengakuan ini terkandung kesalahannnya sendiri. Daniel memohon pengampunan kepada Allah. Tatkala Daniel sibuk berdoa, Gabriel datang atas suruhan Allah untuk membuat Daniel penuh hikmat pengertian. Nubuatan tentang tujuh puluh kali tujuh masa ialah bahwa Allah sudah menetapkan suatu masa tertentu, untuk menggenapkan pemulihan umat-Nya dari perhambaan. Tujuh puluh kali tujuh masa ditentukan guna menyatakan enam hal, yaitu, untuk melenyapkan kefasikan, untuk mengakhiri dosa, untuk menghapuskan kesalahan, untuk mendatangkan keadilan yang kekal, untu kmenggenapkan penglihatan dan nabi, serta untuk mengurapi yang maha kudus. Sampai pada kedatangan seorang yang diurapi, seorang raja, maksudnya seorang yang diurapi dan seorang raja. Raja itu akan membuat perjanjian itu menjadi berat. Perjanjian yang akan berlaku ialah pejanjian kasih karunia yang dialamnya Mesias mengerjakan keselamatan bagi umat-Nya melalui hidup dan kematian-Nya. ${ }^{7}$

Penglihatan Daniel Mengenai kesusahan yang besar, artinya merujuk untuk waktu yang lama. Daniel, engkau orang yang dikasibi. bnd 9:23. Daniel dikasihi oleh Allah dan diberikan semangat dan disediakan untuk mendengarkan berita berkaitan dengan hari-hari yang terakhir, yaitu akhir zaman. ${ }^{8}$ Daniel

'Siahaan, Tafsiran Alkitab, 197-205.

7 Donald Guthrie, dkk, Tafsiran Alkitab Masa Kini 2: Ayub sampai Maleaki, Terjemahan (Jakarta: BPK Gunung Mulia, 1985), 563-565. 8 Ibid, 567. 
diperintahkan memeteraikan perkataan-perkataan yang dinyatakan kepadanya itu sampai pada akhir zaman. Pengetahuan akan maksud-maksud Allah sudah ada di bumi dan tercatat dalam Kitab Suci, dan manusia akan berlalu lalang kian kemari tanpa hasil, karena tidak mencari ke dalam Kitab Suci. Bilangan-bilangan dalam Dan.12:11-12 harus dilihat sebagai lambang, angka ke-1290 hari melambangkan masa penganiayaan oleh Antiokhus Epifanes IV, dan angka ke-1335 hari melambangkan seluruh masa penganiayaan sampai pada kesudahan. Kepada Daniel diberitahukan kepastian keselamatannya, dan akan mendapat bagiannya pada kesudahan zaman. ${ }^{9}$

Jadi, menurut Donald Guthrie akhir zaman bukanlah menunjuk kepada akhir dari segala-galanya, juga bukan penghakiman terakhir, tapi kepada zaman penderitaan yang akan menimpa Israel. Merujuk kepada penindasan yang dilakukan Antiokhus IV.

\section{Kelompok Futuris}

Mewakili kelompok futuris, penulis mengambil tiga pandangan/tafsiran dari para ahli teologi, di antara:

\section{Lynne Newewll}

Pasal 12 mencatat tentang kesesakan orang-orang Israel dan penderitaan di bawah Antiokhus Epifanes IV. Namun waktu kesesakan dan penderitaan yang dimaksudkan di sini akan melebihi semua yang lain yang pernah dialami. Selain itu, pada waktu kesesakan dan penderitaan ini bukan hanya orang-orang Israel saja yang akan menderita. Kenyataan, bahwa "bangsa-bangsa" disebut dalam ayat ini dapat mengacu kepada penderitaan yang lebih luas. Karena malaikat yang sedang menyampaikan surga ini datang justru untuk memberitahukan kepada Daniel apa yang akan terjadi atas bangsanya, ia lalu mengatakan, bahwa pada waktu kesesakan dan penderitaan tersebut "bangsamu akan terluput, yakni barangsiapa yang didapati namanya tertulis dalam kitab itu." Kitab itu adalah kitab kehidupan orang-orang yang namanya tertulis dalam kitab tersebut adalah orang-orang yang benar, yakni orang-orang yang takut akan Tuhan dan menghormatinya. Hal yang akan berakhir dari kehidupan Daniel. Daniel disuruh pergi dan meneruskan hidupnya bagi Tuhan. Ia tidak memikirkan hal-hal yang

${ }^{9}$ Ibid, 569. 
dinyatakan kepadanya, sehingga menjadi khawatir karenanya atau bingung karena tidak memahaminya. Ia harus tetap setia kepada Tuhan dan hidup dengan bijak seperti dahulu, sampai akhir hidupnya. ${ }^{10}$

Orang-orang bijaksana adalah orang yang mengenal Allah dan memahami surga-Nya serta menghayatinya. Daniel dan teman-temannya adalah orang-orang yang bijaksana bahkan Daniel dihormati sebagai orang yang paling bijaksana diseluruh kerajaan Babel, kesetiaan Daniel kepada Allah hidupnya yang benar dan kesaksian yang diberikannya kepada raja-raja dan orang-orang lain sepuaya mereka dapat mengenal dan menghormati Allah. "sembunyikanlah segala surga itu" yaitu mengenai masa depan yang masih jauh. Kemudian. "meteraikanlah kitab itu" yaitu menjamin keasliannya untuk memeliharanya. ${ }^{11}$

Jadi, akhir zaman menurut Newewll, bukan hanya berbicara mengenai penderitaan yang dialami oleh orang-orang Israel pada zaman Antiokhus IV, tetapi merujuk kepada penderitaan yang lebih luas, dan jauh ke depan. Dengan kata lain akhir zaman dimengerti sebagai sesuatu yang akan terjadi dimasa yang akan datang.

\section{Hippolytus \& Irenaeus}

Hippolytus (wafat 235M) mengajarkan dalam komentar kitab Daniel 12:1, bahwa akan terjadi masa kesulitan setelah kedatangan Antikris yang menyebabkan kehancuran, baru setelah itu Kristus akan datang terakhir kali dari surga, yang membawa api dan pengadilan yang adil bagi mereka yang menolak untuk percaya kepada-Nya. Irenaeus $(125 \mathrm{M}-203 \mathrm{M})$ adalah murid Policarpus, yang adalah murid Rasul Yohanes, mengatakan bahwa ke-10 raja yang disebut dalam Dan.7:24 dan Why.17:12, akan memberikan kerajaan mereka kepada Antikris, dan mengusir Gereja. Tetapi, para orang beriman akan bertemu dengan Tuhan pada kebangkitan orang-orang benar, yang

${ }^{10}$ Lynne Newewll, Kitab Daniel (Malang: Literatur SAAT, 2011),346.

11 Ibid, 349. 
akan terjadi setelah kedatangan Antikris, dan kehancuran semua bangsa di bawah kepemimpinannya. ${ }^{12}$

Jadi Hippolytus \& Irenaeus, akhir zaman berbicara mengenai kedatangan Kristus, dan orang-orang benar akan dibangkitkan, sedangkan orang-orang fasik akan dibinasakan.

\section{Ronal S. Walace}

Nubuatan tentang tujuh puluh kali tujuh masa dalam Dan. 9 merujuk kepada kedatangan seorang yang diurapi. Daniel menerima satu penglihatan yang menyatakan akan tibanya satu masa penderitaan dan pencobaan dahsyat yang melibatkan dirinya dalam satu tugas yang berat. Ini adalah surga terakhir tentang masa depan yang terjadi. surga Allah dinyatakan kepada Daniel secara langsung dan lebih dekat daripada sebelumnya, dan menuntut penyerahan diri dan ketaatan secara mutlak. Penglihtan yang dihadapinya sekarang, merupakan satu panggilan baginya untuk menyerahkan seluruh kehendak dan pikirannya. Sementara Daniel bergumul untuk mengerti, "Daniel merendabkan dirinya di hadapan Allab" dan merasa bahwa kebenaran hanya bisa diterima bila seseorang menyerahkan hatinya kepada pemberi wahyu itu, dan rela menerima semua akibat praktis dari pemahaman tentang kebenaran itu, termasuk kerelaan untuk menaatinya. Aspek penting dari wahyu ini adalah konflik dan ketegangan antara kuasa duniawi dan umat Allah tercermin dalam kenyataan surgawi, dan juga terjadi disana. Konsep tentang konflik surgawi yang mempengaruhi dan dipengaruhi oleh apa yang terjadi di dunia, juga dicatat dalam kitab Wahyu. Penglihatan khusus dalam kitab Wahyu berakhir dengan gambaran tentang setan sedang menuju ke lobang tak berdasar, dibuang ke dunia sebagai satu kuasa yang sudah dipatahkan, tapi masih mampu untuk mengacaukan dan menghalangi pekerjaan Allah dan umat Allah untuk sementara. ${ }^{13}$

Pada Dan.11-12, memperkenalkan satu wahyu lisan dan bukan penglihatan. Inti berita yang disampaikan, diberikan dalam bentuk sebuah

12 Paul Thigpen, The Rapture Trap (West Chester PA: Ascension Press, 2001), 132-140.

${ }^{13}$ Ronal S. Walace, Seri Pemahaman dan penerapan Amanat Alkitab Masa Kini: Daniel (Jakarta: Komunkasi Bina kasih, 2010), 250-264. 
narasi yang disampikan secara lisan. Bentuk komunikasi ini, lain sekali dengan sebelumnya yang berupa penglihatan-penglihatan yang dilihat Daniel dalam pasal 7-8. Harus dianggap bahwa wahyu ini adalah klimaks dari semua wahyu yang disampaikan pada Daniel. Di dalam seluruh kitab suci, Allah selalu berkomunikasi dengan manusia selain menggunakan lambang visual, juga verbal. Pasal ini menceritakan kembali satu periode yang sepintas lalu telah dilihat dalam penglihatan di pasal 8, tentang domba jantan, kambing jantan, keempat tanduk dan tanduk kecil. Dalam ay. 6 berbicara tentang peperangan, perserikatan, dan pengaruh timbal balik antara raja-raja bagian utara dan selatan. Bagian ini mempunyai hubungan dengan bagian sejarah yang sudah diceritakan sebelumnya secara terperinci. Bila melihat alkitab secara keseluruhan dengan sungguh, hendaknya memiliki pandangan bahwa Allah, adalah Allah selaku pribadi, juga persekutuan; Allah mengendalikan sejarah sebegitu rupa sehingga memberikan kesempatan bagi manusia untuk mengambil keputusan secara bebas, dan juga pertobatan bagi setiap orang yang secara tulus memohonkannya. Penulis Daniel berbicara secara jelas tentang apa yang akan terjadi pada akhir sejarah. Zaman akhir adalah sesuatu yang masih jauh, juga dari fakta dan keterangan sejarah yang diberikan secra terinci tentang raja-raja dari Dinasti Saleukus dan Ptolemus. ${ }^{14}$

Hal utama yang diberitakan dalam kitab Daniel adalah tidak seorang pun dari orang pilihan Allah itu akan hilang. Nama-nama mereka dicatat dalam buku catatan tentang umat Allah dan maksud-maksud Allah, dan apa yang tertulis akan terlaksana. Akhir dari wahyu terakhir ini memberikan kepada Daniel satu keyakinan bahwa Daniel telah menerima segala sesuatu yang harus dikatakan dan disingkapkan mengenai akhir zaman kepadanya. Akan tetapi Daniel tidak dapat memperoleh pemahaman yang jelas tentang kapan zaman akhir itu akan tiba. Bila zaman akhir itu mendekat, akan terjadi banyak kesusahan. Untuk itu dibutuhkan keberanian, seperti juga kesabaran dan ketabahan. Karena itu, orang lebih membutuhkan hikmat dari pada keberanian. Hikmat telah diuraikan panjang lebar dalam kitab Amsal, juga dalam beberapa bagian kitab Daniel. Hikmat itu tentu pemberian dari Allah. Daniel akhirnya diyakinkan bahwa akan menemukan satu jalan yang

14 Ibid, 265-276. 
senantiasa terbuka dihadapannya. Daniel berjalan pada jalannya sendiri di hadapan Allah dan mendapat tempat di mana akan berdiri dengan tidak gentar di depan kehadiran Allah, dan menemukan ketenangannya. Dalam bagian penutup mengenai hal ini, Daniel menambahkan satu hal yang amat mengesankan dari seluruh kitab yaitu, Allah menempatkan tiap orang dan rencananya dalam rancangannya, dan dalam tujuan-Nya di masa depan. Janji-Nya kepada Daniel bahwa "engkau akan beristirahat" menunjuk pada satu keadaan dalam dunia baru yang akan dikunjungi Daniel. ${ }^{15}$

Jadi, akhir zaman menurut Walace adalah sesuatu yang masih jauh terjadi. Dengan kata lain, Walace berpandangan akhir zaman itu merupakan futuris.

\section{KONTEKS DEKAT DANIEL PASAL 12}

Kitab Daniel pasal 12 berbicara mengenai akhir zaman, ini merupakan lanjutan dari pasal 11 seharusnya tidak dipisahkan. ${ }^{16}$ Pada waktu itu, waktu yang dimaksudkan ialah waktu yang dibicarakan di pasal 11:40-45. Menurut Siahaan, waktu tersebut disarankan kepada pembaca kitab Daniel bahwa waktu yang dimaksud di ayat-ayat tersebut ialah mengenai hal eskatologi, yaitu akhir zaman, sebab ungkapan yang sama sering terdapat dalam kitab nabi-nabi sebagai pendahuluan kepada nubuat tentang pokok demikian. ${ }^{17}$ Menurut Newell, waktu itu akan muncul Mikhael, pemimpin besar itu yang akan mendampingi umat Allah. Dalam bahasa Ibrani,kata mendampingi secara harfiah berarti "berdiri." Dalam ayat ini dikatakan Mikhael akan "berdiri." Kata tersebut adakalanya dipakai dengan arti "berdiri untuk menentang" seperti dalam Ezr.10:15 dan 2Taw.26:18. Konteks ayat ini ialah peperangan dan permusuhan terhadap umat Tuhan. ${ }^{18}$

"Mikhael, pemimpin besar itu" adalah malaikat yang disebut dalam 10:13 dan 21, yaitu seorang pemimpin di antara para malaikat yang kuat, yang bertugas berperang bagi umat Tuhan (bangsa Israel). Mikhael,

15Ibid, 278-292.

16S.M. Siahaan dan Robert Paterson, Tafsiran Alkitab: Kitab Daniel: Latar Belakang, Tafsiran, dan Pesan, ed. Rika Uli Napitupulu-Simarangkir (Jakarta: BPK. Gunung Mulia, 2001), 97.

${ }^{17} \mathrm{Ibid}, 197$.

${ }^{18}$ Newell, Tafsiran Kitab Daniel, 344. 
penghulu malaikat itu, dulu memimpin para malaikat berperang mengalahkan Iblis dan para malaikatnya dalam peperangan di surga. Lihat juga Why.12:7, juga 1:9. Jadi tugasnya lebih luas daripada berperang bagi orang-orang Israel saja. Seperti halnya yang dikatakan oleh Siahaan bahwa Mikhael adalah pemimpin dan pelindung surgawi bagi umat Israel. ${ }^{19}$

Zaman itu akan disebut zaman kesesakan, karena akan ada suatu waktu kesesakan yang besar, seperti yang belum pernah terjadi sejak bangsa-bangsa sampai pada waktu itu. Kata kesesakan dalam bahasa Ibrani yang dipakai tidak hanya mengacu kepada keadaan, tetapi dapat juga melukiskan perasaan hati orang yang berada dalam keadaan tersebut. ${ }^{20}$

Orang-orang Yahudi memang mengalami kesesakan dan penderitaan di bawah Antiokhus Epifanes, orang-orang Yahudi ditindas dari segi politik, ekonomi dan budaya, dan kemudian sekali lagi pada tahun 70M. waktu tentara dari kerajaan Roma menghancurkan Yerusalem dan Bait Allah, dan pada beberapa waktu di beberapa negara sejak waktu itu. Namun menurut Newell, waktu kesesakan dan penderitaan yang dimaksudkan di sini akan melebihi semua yang lain yang pernah dialami. Selain itu, pada waktu kesesakan dan penderitaan ini bukan hanya orang-orang Yahudi saja yang akan menderita. Kenyataan, bahwa bangsa-bangsa yang disebut dalam ayat ini dapat mengacu kepada penderitaan yang lebih meluas. Konteks di mana Tuhan Yesus memakai ayat ini yakni Mat.24, serta perikop-perikop lain dalam Perjanjian Baru, misalnya 2.Tes.2:1-12 dan beberapa bagian kitab Wahyu menyatakan bahwa waktu kesesakan dan penderitaan tersebut dialami oleh semua umat Tuhan dari bangsa manapun. ${ }^{21}$

Malaikat yang sedang menyampaikan surga ini datang justru untuk memberitahukan kepada Daniel apa yang akan terjadi di atas bangsanya (Dan.10:14). Malaikat itu berkata bahwa pada waktu kesesakan dan penderitaan tersebut, "Bangsamu akan terluput, yakni barangsiapa yang didapati namanya tertulis dalam kitab itu." 22 Sebab dalam kesesakan atau penderitaan Tuhan akan melindungi orang-orang yang tertulis di dalam kitab

\footnotetext{
${ }^{19}$ Siahaan, Tafsiran Alkitab: Kitab Daniel, 197.

${ }^{20}$ Newell, Tafsiran Kitab Daniel, 345-346.

${ }^{21}$ Ibid, 345-346.

${ }^{22}$ Collins, Tafsir Deutoronika 4, 79.
} 
kehidupan. Orang-orang yang namanya tertulis dalam kitab kehidupan akan dilindungi oleh malaikat Mikhael yang merupakan utusan Tuhan. ${ }^{23}$

Jika melihat secara langsung di dalam kitab Daniel mulai pada Mikhael datang. Hal ini sama dengan awal waktu 1260 tahun. Di mana akan terjadi penganiayaan yang disebut dengan penganiayaan hari sabat. Demikian juga pada akhir zaman akan ada suatu waktu seruan nyaring peringatan kepada dunia, yang berlangsung selama tiga setengah tahun (Dan.12:7). Selama 30 hari terakhir dari 1290 hari, tujuh malapetaka terakhir akan jatuh (why.16). Waktu 1290 hari akan dimulai dengan penganiayaan karena hari sabat dan hukum pengudusan hari Minggu secara global. Akan ada waktu 1335 hari pembebasan dari tekanan dan siksaan.

Menurut Collins, dalam menjelaskan eskatologi Daniel setidaknya dua cara dalam memahaminya:

1. Pembebasan ilahi terhadap para pahlawan adalah penegasan bukan pembebasan di masa depan untuk orang-orang Yahudi, tetapi kualitas hidup tertentu yang tersedia untuk menemukan Yahudi, yaitu kesetiaan kepada Tuhan Yahudi;

2. Merujuk ke tingkatan lebih tinggi, bahwa para pahlawan di akhir cerita adalah penegasan nilai sosial dan politik kesetiaan. Gagasan tentang 'kerajaan orang-orang suci' lebih dari satu dimensi disampaikan dalam bahasa pasal 2, di mana masalah langsung kedaulatan antara raja dan Tuhan dipertajam oleh prediksi masa depan, akhir, dan kerajaan abadi. Sangat mungkin untuk menemukan gagasan yang sama dalam visi Daniel apakah kerajaan malaikat itu benar-benar digambarkan atau tidak. Pertanyaan eksegetikalnya adalah apakah pasal 7 menggambarkan kerajaan malaikat atau, secara simbolis, manusia.

\section{STRUKTUR DANIEL 12}

Mempelajari struktur sebuah tulisan biasanya akan bersentuhan dengan isu tentang kesatuan pesan yang ada dalam tulisan tersebut dan identitas penulis yang sama. Mengenai struktur dari Daniel pasal 12, ada beberapa

${ }^{23}$ Siahaan, Tafsiran Alkitab: Kitab Daniel, 197. 
pembagian yang berbeda-beda di antara para ahli. Pertama, menurut Carol A. Newsom ${ }^{24}$ yang membagi Daniel pasal 12 menjadi 7 bagian:

Dan 12:1-3 : Prediksi pembebasan dan kebangkitan

Dan 12:4 : Perintah kepada Daniel untuk menyegel kitab

Dan 12:5 : Daniel melihat dua malaikat

Dan 12:6-7 : Dialog di antara para malaikat tentang waktu akhir akhir

Dan 12:8-10 : Dialog antara Daniel dan malaikat tentang waktu

Dan 12:11-12 : Jumlah hari yang tersisa sampai waktu akhir

Dan12:13 : Pemberitahuan malaikat kepada Daniel.

Kedua, Alexander A. Di Lella memiliki pembagian yang sedikit berbeda dengan Carol A. Newsom. Di Lella membagi Daniel pasal 12, menjadi satu kesatuan atau satu rangkaian dari Daniel pasal 10 (Dan 10:1 12:13) atau disebut sebagai wahyu akhir, dan dibagi menjadi 3 bagian utama. ${ }^{25}$

Dan 10:1 - 11:1 : Pembuka

Dan 11:2 - 12:4 : Wahyu mengenai masa depan

Dan 12:5-13 : Penutup

Jika diperhatikan dengan seksama, Daniel pasal 12 dimulai dari ayat 1 sampai ayat 13 saling berhubungan dalam pola chiastic $\left(\mathrm{ABCD} / / \mathrm{D}^{1} \mathrm{C}^{1} \mathrm{~B}^{1} \mathrm{~A}^{1}\right)$.

${ }^{24}$ Carol A. Newsom \& Brennan W. Breed, The Old Testament Library: Daniel A Commentary (Louisville: Westminster Jhon Knox Press, 2014), 360.

${ }^{25}$ Louis Hartman, \& Alexander A. Di Lella. The Anchor Bible, The Book of Daniel (New York: Doubleday \& Company, Inc, 1978), 255- 261. 


\begin{tabular}{|c|c|c|c|}
\hline \multirow[b]{2}{*}{$\mathrm{D}$} & Ayat 4 & \multirow[b]{2}{*}{$\begin{array}{l}\mathrm{D}^{1} \\
\text { tetapi }\end{array}$} & Ayat $8-9$ \\
\hline & $\begin{array}{l}\text { Tetapi engkau,'Daniel' } \\
\text { sembunyikanlah surga itu } \\
\text { sampai pada 'akhir } \\
\text { zaman' }\end{array}$ & & $\begin{array}{l}\text { Adapun 'aku', mendengar } \\
\text { tidak memahaminya } \\
\text { Pergilah 'Daniel', sebab } \\
\text { surga ini akan tinggal } \\
\text { tersembunyi dan } \\
\text { termeteraikan sampai } \\
\text { 'akhir zaman'. }\end{array}$ \\
\hline \multirow[b]{2}{*}{ C } & Ayat $2-3$ & \multirow[b]{2}{*}{$\begin{array}{l}\mathrm{C}^{1} \\
\text { disucika } \\
\text { tetapi }\end{array}$} & Ayat 10 \\
\hline & $\begin{array}{l}\text { 'Orang-orang' yang telah } \\
\text { tidur dalam Debu tanah } \\
\text { akan bangun, mendapat } \\
\text { Hidup kekal, kehinaan } \\
\text { dan kengerian kekal. } \\
\text { 'orang-orang bijak' akan } \\
\text { bercahaya. }\end{array}$ & & $\begin{array}{l}\text { 'Banyak orang' akan } \\
\text { dimurnikan dan diuji, } \\
\text { orang } \\
\text { fasik akan berlaku fasik, } \\
\text { tidak akan memahami, } \\
\text { 'orang-orang bijak' akan } \\
\text { memahaminya. }\end{array}$ \\
\hline & Ayat 1 & & Avat 11 \\
\hline B & $\begin{array}{l}\text { Akan ada suatu waktu } \\
\text { kesesakan yang besar atas } \\
\text { suatu bangsa akan } \\
\text { terluput namanya tertulis } \\
\text { dalam kitab }\end{array}$ & $\mathrm{B}^{1}$ & $\begin{array}{l}\text { Sejak dihentikan korban } \\
\text { sehari-hari dan ditegakkan } \\
\text { dewa-dewa kekejian yang } \\
\text { membinasakan itu. }\end{array}$ \\
\hline & Ayat 1 & & Ayat $12-13$ \\
\hline
\end{tabular}




\begin{tabular}{|l|ll|}
\hline A $\quad \begin{array}{ll}\text { pada waktu itu, muncul } \\
\text { Mikhael pemimpin besar, } \\
\text { yang mendampingi anak- } \\
\text { anak bangsamu }\end{array}$ & berbahagialah orang yang \\
& tetap menanti-nanti. \\
& $\begin{array}{l}\text { Engkau akan bernubuat } \\
\text { dan akan bangkit untuk } \\
\end{array}$ & $\begin{array}{l}\text { mendapat bagianmu pada } \\
\text { kesudahan zaman. }\end{array}$ \\
\hline
\end{tabular}

Ayat 1 dan 2 menjadi satu rangkaian atau parallel, dan saling berhubungan dengan ayat 10-13. Ayat 1 berhubungan dengan ayat 12 mengenai kebahagian bagi orang-orang yang setia menantikan kemunculan seorang pemimpin hebat yang akan menjadi pelindung bagi bangsa Israel, yang akan membebaskan mereka dari kekuasaan penguasa yang lalim. Namun ayat 1 juga masih berhubungan dengan ayat 11 mengenai akan terjadinya suatu kesesakan besar atas bangsa Israel yang dimulai sejak dihentikannya korban sehari-hari dan ditegakkannya dewa-dewa kekejian yang membinasakan. Akan tetapi mereka yang namanya tertulis dalam kitab akan terluput dari kesesakan besar tersebut. Masa kesesakkan besar bisa dikatakan sama dengan masa kekelaman. Lalu ayat 2 berhubungan dengan ayat 10 mengenai kebangkitan orang-orang yang sudah meninggal, ada yang dibangkitkan untuk memperoleh hidup kekal, namun ada juga yang dibangkitkan untuk mengalami kehinaan dan kengerian kekal. Jadi, pada masa kesesakan orang-orang akan diuji iman mereka supaya disucikan dan dimurnikan, namun orang fasik tetap akan berlaku fasik karena mereka tidak memahaminya, sedangkan orang bijak akan memahaminya.

Ayat 4 berhubungan dengan ayat $8-9$ mengenai perintah penyegelan atau pemeteraian surga sampai akhir zaman. Tokoh yang di ayat 4 dengan tokoh di ayat $8-9$ adalah sama yaitu Daniel, yang disuruh oleh malaikat Tuhan untuk menyegel surga yang sudah Daniel dengar dan lihat. Mengenai batas penyegelan atau pemeteraian, baik di ayat 4 maupun di ayat $8-9$ adalah sama yaitu sampai akhir zaman. 


\section{STUDI KATA}

Kata pada waktu itu, memakai kata "eth/ waktu (suatu peristiwa), waktu (biasa), pengalaman, keberuntungan kejadian, kesempatan. Kata "eth/ צy" digunakan sebanyak 296x: merujuk kepada kata waktu (257x), musim (16x), kapan (7x), selalu (4x), sore hari (2x), bermacammacam (10x). Jadi kata "eth/ עֵת di dalam Daniel 12:1 itu merujuk kepada waktu.

Kata pemimpin besar, memakai kata "gadowl/ לiד besar: besar (besar dan luas), jumlahnya, dalam intensitas, keras (dalam suara), lebih tua (dalam usia), besar dalam arti penting: hal-hal penting, hebat, terhormat (laki-laki), Tuhan sendiri (Tuhan). Kata "gadowl/לiדָ: digunakan sebanyak 529x: merujuk kepada kata hebat (397x), tinggi (22x), lebih besar (19x), keras (9x), terbesar (9x), tua (8x), pria hebat (8x), perkasa (7x), sulung (6x), bermacam-macam (44x). jadi, kata "gadowl/ לiדị̦" Daniel 12:1 itu merujuk kepada seorang pemimpin yang hebat.

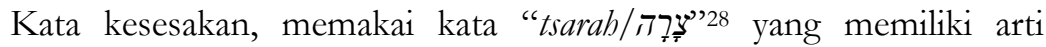

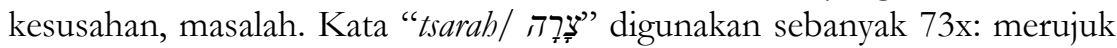
kepada kata masalah (44x), marabahaya (8x), penderitaan (7x), kesulitan (5x), kesedihan (5x), kesengsaraan (3x), musuh (1x). jadi, kata "tsarah/ Daniel 12:1 itu merujuk kepada kepada masalah-masalah yang akan dihadapi oleh orang Israel.

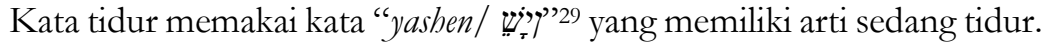

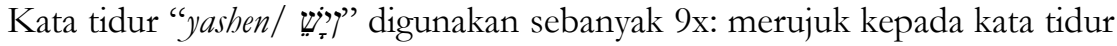
(8x), tertidur (1x). jadi, kata “yashen/ ש্ָ’’’ dalam Daniel 12:2 merujuk kepada orang-orang yang sudah mati.

${ }^{26}$ Strong's H6256-'eth. https://www.blueletterbible.org/lang/lexicon/. Diunduh pada tanggal 09 November 2018.

${ }^{27}$ Strong's H1419 -gadowl. https://www.blueletterbible.org/lang/ lexicon. Diunduh pada tanggal 09 November 2018.

28 Strong's H6869 - tsarah. https://www.blueletterbible.org/lang/ lexicon/. Diunduh pada tanggal 09 November 2018.

${ }^{29}$ Strong's H3463 -yashen. https://www.blueletterbible.org/lang/ lexicon. Diunduh pada tanggal 09 November 2018. 
Kata akan bangun memakai kata "quwts/קוּ"30 yang memiliki arti untuk bangun, bangun; untuk membangunkan, membangkitkan, menunjukkan tanda-tanda bangun. Kata "quwts/Y קוּ" digunakan sebanyak 22x: merujuk kepada kata bangun (18x), bangun (2x), bangun (1x), tonton (1x). jadi, "quwts/קוּץ dalam Daniel 12:2 merujuk kepada kebangkitan dari orangorang yang sudah mati.

Kata hidup memakai kata "chay/ ${ }^{\prime}$ "31 yang memiliki arti 1) hidup: hijau (dari vegetasi), mengalir, segar (air), hidup, aktif (manusia), menghidupkan kembali (musim semi); 2) keluarga; 3) hidup (abstrak tegas): kehidupan, rezeki, pemeliharaan; 4) makhluk hidup, hewan: hewan, kehidupan, nafsu makan, kebangunan rohani, pembaruan; 5) masyarakat. Kata "chay/ 'ח " digunakan sebanyak 501x: merujuk kepada kata hidup (197x), hidup (144x), binatang (76x), hidup (31x), makhluk (15x), berlari (7x), makhluk hidup (6x), mentah (6x), bermacam-macam (19x). Sedangkan kata kekal memakai kata

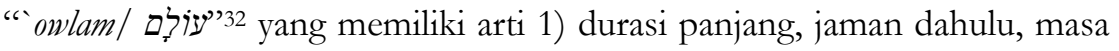
depan, selamanya, abadi, abadi, abadi, abadi, tua, kuno, dunia 1a) waktu kuno, waktu yang lama (dari masa lalu) 1b) (masa depan) 1b1) selamanya, selalu 1b2) eksistensi yang berkelanjutan, abadi 1b3) abadi, masa depan tak terbatas atau tak berujung, keabadian. Kata "owlam/ עי "ל digunakan sebanyak 439x: merujuk kepada kata.

Jadi, yang dimaksud dengan hidup kekal dalam Daniel 12:2 adalah kehidupan abadi tanpa batas.

Kata kehinaan memakai kata "cherpah/ 73x: merujuk kepada kata mencela (67x), malu (3x), menegur (2x), mencela

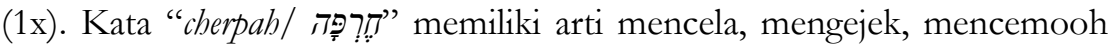

${ }^{30}$ Strong's H6974 - quwts. https://www.blueletterbible.org/lang/ lexicon/. Diunduh pada tanggal 09 November 2018.

${ }^{31}$ Strong's H2416 - chay. https://www.blueletterbible.org/lang/ lexicon/. Diunduh pada tanggal 09 November 2018.

${ }^{32}$ Strong's H5769 - 'owlam. https://www.blueletterbible.org/lang/ lexicon/. Diunduh pada tanggal 09 November 2018.

33Strong's H2781 - cherpah. https://www.blueletterbible.org/lang/ lexicon/. Diunduh pada tanggal 09 November 2018. 
(atas musuh). Jadi, yang dimaksud dengan kehinaan kekal dalam Daniel 12:2 adalah keadaan malu yang tidak ada habisnya.

Kata kengerian memakai kata "dĕra'own/ pisר? ?ִ?"34 digunakan sebanyak 2x: merujuk kepada kata keengganan, dan kebencian. Kata "dĕra'own/ jiאר? ?ִ?" memiliki arti sebuah objek keengganan: —menghindarkan, menghina. Jadi, yang dimaksud dengan kengerian kekal dalam Dan.12:2 adalah keadaan yang menjiijikan selamanya.

Kata bijaksana memakai kata "sakal/ merujuk kepada kata mengerti (12x), bijaksana (12x), makmur (8x), bijaksana (6x), pengertian (5x), pertimbangkan (4x), ajarkan (3x), prudent

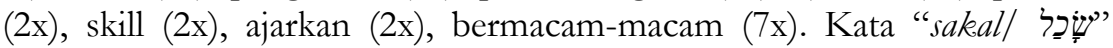
memiliki arti untuk (secara sengaja, membuat atau bertindak) dengan hatihati dan karenanya, cerdas: —mempertimbangkan, ahli, mengajar, sejahtera, (kesepakatan) yang bijaksana (-ly), (memberi) keterampilan (-memiliki), memiliki keberhasilan yang baik, mengajar, (memiliki, membuat) memahami (-ing), kebijaksanaan, (menjadi, berperilaku, mempertimbangkan, membuat) bijak (-ly), membimbing dengan sadar. Jadi, yang dimaksud dengan orang-orang bijak dalam Dan.12:3 adalah orangorang yang bisa mengambil keputusan dalam segala sesuatu dengan mempertimbangkan dari berbagai segi, sehingga diperoleh suatu keputusan yang tepat.

Jadi, Daniel 12:1-3, merupakan suatu rangkaian pembukaan dari pasal 12. kata pertama yang dipakai adalah "pada waktu itu" merujuk kepada suatu waktu, ada 3 hal kesejajaran dari yang merujuk kepada kata "pada waktu itu". Pertama, waktu munculnya seorang pemimpin besar, yang dimaksud dengan pemimpin besar yaitu Mikhael. Kedua, waktu kesesakan besar, hal itu merujuk kepada suatu keadaan di mana orang-orang Israel akan mengalami permasalahan yang luar biasa dashyatnya. Ketiga, waktu kebangkitan dari orang-orang yang sudah meninggal, hal ini merujuk kepada di mana orangorang bijak akan bercahaya dan memperoleh hidup yang kekal

34 Strong's H1860 - děra'own. https://www.blueletterbible.org/lang/ lexicon/. Diunduh pada tanggal 09 November 2018.

35 Strong's H7919 - sakal. https://www.blueletterbible.org/lang/ lexicon/. Diunduh pada tanggal 09 November 2018. 


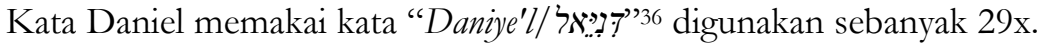

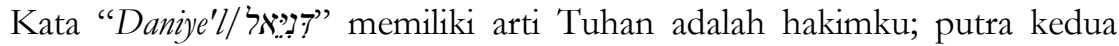
Daud, dari Abigail; keempat dari para nabi yang lebih besar, yang diambil sebagai sandera dalam deportasi pertama ke Babel, karena karunia Tuhan dari penafsiran mimpi, ia menjadi komandan ke-2 kerajaan Babel dan berlangsung sampai akhir kerajaan Babilonia dan masuk ke kerajaan Persia. Ramalannya adalah kunci untuk memahami peristiwa akhir zaman. Dicatat untuk kemurnian dan kekudusannya oleh nabi kontemporer, seperti Yehezkiel dan Belteshazzar; seorang imam garis keturunan Ithamar yang menyegel perjanjian dengan Nehemia. Jadi yang dimaksud dengan "Daniel" dalam pasal 12:4 adalah seorang yang saleh dihadapan Allah.

Kata akhir zaman memakai kata "qets/ r.?"37 digunakan sebanyak 67x: merujuk kepada kata akhir (52x), setelah (10x), perbatasan (3x), tak terbatas (1x), proses (1x). Kata "qets/ Y??" memiliki arti pada akhir (waktu), akhir (ruang). Jadi yang dimaksud dengan akhir zaman dalam Dan.12:4 adalah akhir dari waktu.

Jadi, yang dimaksud dengan Dan.12:4 adalah perintah kepada Daniel yang merupakan orang saleh untuk menyembunyikan dan menyegel surga Tuhan yang sudah disampaikan oleh malaikat Tuhan sampai kepada akhir dari dunia.

Di dalam Dan.12:5 dikatakan bahwa Daniel, melihat dua orang berdiri ditepi sungai. Kata yang digunakan untuk tepi atau batas adalah kata

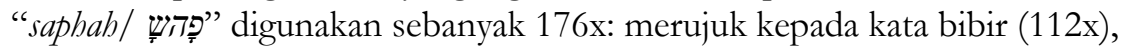
sungai (10x), penuh (8x), tepi (8x), bahasa (7x), ucapan (6x), pantai (6x), tepi jurang (5x), perbatasan (3x), sisi (3x), membosankan (2x), sia-sia (2x),

36 Strong's H1840 - Daniye'l. https://www.blueletterbible.org/lang/ lexicon/. Diunduh pada tanggal 09 November 2018.

${ }^{37}$ Strong's H7093 - qets. https://www.blueletterbible.org/lang/lexicon. Diunduh pada tanggal 09 November 2018. 
bermacam-macam (4x). Jadi yang dimaksud dengan tepi atau batas dalam Dan.12:5 adalah batas alam.

Jadi, Dan.12:5 merupakan penglihatan Daniel mengenai dua malaikat Tuhan, dan ada pemisah di antara mereka, Daniel berada di alam manusia (duniawi) sedangkan kedua malaikat berada di alam surgawi (adikodrati).

Dan.12:6-7 berisikan percakapan antara malaikat Tuhan mengenai kesudahan zaman. Kata satu masa, dua masa dan setengah masa, merujuk kepada sebuah waktu. Dalam bahsa Ibrani memakai kata "kalah/ digunakan sebanyak 206x: merujuk kepada kata mengkonsumsi (57x), akhir $(44 x)$, selesai (20x), gagal (18x), selesai (12x), selesai (9x), menghabiskan (8x), berakhir $(7 x)$, ditentukan $(4 x)$, pergi $(3 x)$, memenuhi $(3 x)$, pingsan $(2 x)$, menghancurkan (2x), kiri (2x), buang (2x), lain-lain (13x). Kata "kalab/ memiliki arti untuk mengakhiri, apakah intransitif (untuk berhenti, selesai, musnah) atau transitif (untuk menyelesaikan, mempersiapkan, mengkonsumsi): - mencapai, menghentikan, mengkonsumsi (pergi), menentukan, menghancurkan (sepenuhnya), menjadi (ketika ... ada) dilakukan, (menjadi) akhir, berakhir, (menyebabkan) gagal, pingsan, selesaikan, penuhi, $\times$ penuh, $\times$ miliki, tinggalkan (tidak aktif), panjang, teruskan, semuanya menuai, bersihkan, habiskan , cukup bawa, buang. Jadi, yang dimaksud dengan satu masa, dua masa dan setengah masa dalam Dan.12:7 adalah waktu yang diberikan untuk menyelesaikan atau berakhirnya suatu periode.

Jadi, yang dimaksudkan dengan akhir zaman dalam Dan.12:5-7, adalah waktu terjadinya pemusnahan atau penghancuran yang akan dialami oleh musuh-musuh Israel, dalam hal ini adalah berakhirnya kekuasaan Antiokius Efipanes IV.

\section{ESKATOLOGI KITAB DANIEL}

Pada dasarnya paham akhir zaman dalam Perjanjian Lama berakar dalam pengharapan umat Israel akan keselamatan yang akan datang, yang dimaklumkan pertama-tama oleh para nabi dan kemudian oleh para penulis apokaliptik. Nubuatan-nubuatan mengenai akhir zaman diberikan Allah dalam Dan.12:1-4. Sedangkan nubuatan tentang kebangkitan pada akhir 
zaman diberikan dalam Dan 12:1-2 kebangkitan dalam ayat yang kedua terjadi pada waktu kesesakan yang besar. Beberapa gambaran eskatologi yang ada di dalam kitab Daniel.

\section{Turunnya Mesias}

Daniel melihat seorang anak manusia yang turun dengan awan-awan dari langit. Dalam Dan.7:21 dituliskan bahwa tanduk itu akan melawan orang-orang kudus dan mengalahkannya. Hal ini menceritakan mengenai aniaya yang akan terjadi terhadap umat Allah. Daniel menyatakan bahwa sang raja lalim akan menduduki Bait Allah yang dibangun kembali di Yerusalem selama pertengahan masa tujuh tahun dalam Masa Kesukaran dan menyatakan dirinya sebagai Allah (lihat Dan.9:27).

Pada akhir zaman menurut Daniel, akan terjadi suatu penindasan. Bagi mereka orang percaya yang hidup di dunia ini. penindasan bagi orang yang percaya seharusnya dimengerti sebagai ujian dan pemurnian iman mereka. Penganiayaan akan muncul di mana-mana. Mereka menyiksa bukan hanya secara fisik namun secara batin. suatu kengerian yang sepertinya tidak ada ujungnya. Penindasan yang di alami adalah ujian, alat Allah untuk melakukannya adalah para penguasa lalim pada saat itu. Ketekunan dan kesetiaan melakukan surga Tuhan adalah kunci pemeliharaan Tuhan.

Dalam pasal 9 berbicara mengenai tujuh puluh kali tujuh masa (lihat Dan.9:2; Yer.25:11-12). Daniel mulai berdoa, mengaku dosa-dosa bangsanya dan memohon belas-kasihan. Demi menjawab doanya, malaikat Gabriel muncul kepadanya dan mengungkapkan masa depan bangsa Israel melalui masa kesukaran sampai datangnya seorang mesias. Nubuatan dalam Dan.9:24-27 adalah salah satu nubuatan yang paling mengagumkan dalam Alkitab.

Kepercayaan adanya kebangkitan, apapun bentuk yang dapat diambilnya, dekat hubungannya dengan penghakiman yang akan berlangsung. Kepercayaan terhadap kebangkitan dan penghakiman seseorang setelah kematian diperkenalkan dalam Yudaisme. ${ }^{38}$ Penghakiman

${ }^{38}$ Lynne Newell, Kitab Daniel (Malang: Literatur SAAT, 2011), 81. 
yang akan datang adalah suatu peristiwa besar, seluruh jagat sedang menuju ke sana. Ketika Allah menciptakan dunia, Allah telah menyiapkan penghakiman, dan hal-hal yang berkaitan dengan penghakiman. ${ }^{39}$

Rujukan pada hal itu dibuat dalam semua apokalipsis "sejarah" di mana sebagian besar penghakiman itu adalah penghakiman atas semua orang ketimbang atas orang perseorangan dan Allah sendiri akan mengetuainya sebagai hakim (Dan.7:9-14). Tetapi sejalan dengan ini, dalam apokaliptik kitab Daniel misalnya, dibayangkan juga suatu kebangkitan orang perseorangan untuk penghakiman itu; ini menjadi ciri khas yang mencolok dalam sejumlah tulisan apokaliptik belakangan.

Russel berpendapat bahwa kadang-kadang penghakiman itu dibayangkan sebagai bencana maha dahsyat yang akan menimpa semua orang dan semua bangsa; kerusakan akan melanda dunia melalui datangnya banjir dan api. Orang-orang yang tidak mengenal Allah akan dibinasakan dalam peperangan dan guncangan alam. Di lain tempat, penghakiman ini digambarkan suatu Pengadilan agung di saat mana Allah akan duduk di takhta-Nya dan menjatuhkan keputusan-Nya atas bangsa-bangsa di bumi. Hal ini dikatakan oleh Russel berdasarkan beberapa kitab dibayangkan ada dua penghakiman, yang satu menjadi pendahuluan untuk yang berikutnya. Penghakiman yang pertama biasanya berupa bencana maha dahsyat dan yang kedua berupa pengadilan berdasarkan hukum, dan akan diikuti oleh Pengadilan agung pada akhir Kerajaan Mesianis di mana "api neraka" dan "Firdaus kesukaan" akan dinyatakan (7:36).40 Allah akan menghakimi bangsa-bangsa yang menindas umat-Nya dan akan memberikan kekuasaan kepada Anak Manusia. ${ }^{41}$ Inti dari semua ini adalah keyakinan bahwa Allah tidak akan membiarkan umat-Nya binasa; kejahatan akan dihukum dan kebaikan akan diberi pahala. Pengadilan akhir ini adalah tindakan Dia yang maksud dan tujuan-Nya yang kekal pada akhirnya akan digenapi. ${ }^{42}$

Kedatangan mesias sangat dinantikan oleh umat Yahudi. Kata "Mesias" berasal dari kata Ibrani yang berarti "Yang Diurapi". Kedatangan

${ }^{39}$ D. S. Russel, Penyingkapan Ilabi: Pengantar ke dalam Apokaliptik Yahudi, alih bahasa: Ioanes Rakhmat (Jakarta: Bpk. Gunung Mulia, 2007), 134.

40Ibid, 135.

${ }^{41}$ Harry Mowley, Penuntun ke Dalam Nubuat Perjanjian Lama (Jakarta: BPK Gunung Mulia, 2000), 115-116.

${ }^{42}$ Russel, Penyingkapan Ilabi, 135. 
mesias memiliki makna yaitu berakhirnya pemerintahan tirani. Mesias datang bersama dengan orang pilihannya, Mesias datang tidak sendirian. Tetapi Mesias bersama dengan umat-Nya, orang suci-Nya, Daniel menyebut mereka sebagai orang-orang yang bijak. Mereka bercahaya seperti cahaya cakrawala, mereka lah yang akan menuntun umat manusia kepada jalan kebenaran. Menuju kepada kebenaran yang sejati yaitu kepada Allah. Mereka akan memerintah pada masanya.

\section{Perang}

Perang adalah sebuah aksi fisik dan non fisik (dalam arti sempit, adalah kondisi permusuhan dengan menggunakan kekerasan) antara dua atau lebih kelompok manusia. Untuk memperoleh kemerdekaan Indonesia harus merebutnya dengan peperangan sekian ratus tahun. Tentu bukan hal yang mudah dan remeh. Perang sebenarnya telah ada sejak zaman PL. Bangsa Israel merebut tanah perjanjian dengan perang. Namun itu bukanlah akhir zaman. Daniel menjelaskan dalam penglihatannya adanya perang. Maksudnya adalah ketika perang itu berhenti. Berarti selagi masih ada perang belum terjadi akhir zaman. Berhentinya perang bukan berarti berakhirnya penderitaan. Perang adalah awal dari pada akhir zaman. Perang berakhir, karena Mesias datang yang ke dua kalinya. Dia sendiri yang akan memerintah dan dia sendirilah yang akan menghakimi setiap manusia.

Dalam Daniel pasal 10, Daniel mendapat penglihatan yang disampaikan oleh malaikat. Perhatian utama apokaliptik kitab Daniel 10 ialah memperlihatkan bagaimana Daniel merasa digagahi oleh pewahyuan itu. Meskipun pewahyuan itu sebagian besar menyangkut peristiwa-peristiwa sejarah helenistik, namun tidak disajikan sebagai suatu pelajaran sejarah, melainkan sebagai suatu pewahyuan mengenai arti rahasia peristiwaperistiwa itu. ${ }^{43}$

Pewahyuan yang diberikan malaikat itu mengenai suatu "peperangan besar (ay. 1). Hal ini berdasarkan arti kata kesusahan dalam bahasa Ibrani

43John J. Collins, Tafsir Deutoronika 4: Daniel, alih bahasa: Bosco Carvallo \& Martin Harun (Yogyakarta: Kanisius, 1990), 73. 
adalah 'tentara' atau perang. Jadi menurut Newell, terjemahan yang lebih tepat dalam ayat ini adalah peperangan atau pergumulan. Namun, para penafsir memakai kata peperangan sebagai terjemahan yang lebih tepat. Makna kalimat itu mengenai peperangan yang besar atau mengenai banyak peperangan. ${ }^{44}$ Peperangan ini dilakukan oleh kerajaan-kerajaan dunia yang saling berperang untuk menguasai dunia, tetapi penguasa yang juga menganiaya umat Allah akan dihancurkan oleh Allah. Pada pasal 11, Daniel mendapat penglihatan bahwa kerajaan Persia akan jatuh ke tangan Yunani (11:2) dan kerajaan Yunani akan terpecah menjadi empat kerajaan (11:3-4). Fokusnya tertuju kepada dua diantara keempat kerajaan itu: Utara dan Selatan, yaitu Seleukis vs Ptolemaus (11:5-20). Kemudian sorotan tertuju kepada "seorang yang hina" (11:21) yang melawan Allah dan menganiaya orang-orang kudus yakni Antiokhus Epifanes (175-164 sM).45

Dari pernyataan-pernyataan di atas dapat disimpulkan bahwa penglihatan mengenai peperangan besar tersebut ialah peperangan antar kerajaan dunia yang ingin menguasai dunia. Di bawah kekuasaan raja yang lalim atau Antiokhus Epifanes IV, berusaha memerangi umat Allah, tetapi Allah membela umat-Nya dengan menghancurkan para penguasa kerajaan dunia, pada waktu itu Tuhan akan datang mendirikan kerajaan-Nya di dunia.

\section{Adanya Kebangkitan Tubuh}

Daniel Pasal 12 merupakan puncak pewahyuan yang panjang dari pasal 10 dan 11, dan juga seluruh Kitab Daniel. Menurut Collins, kematian Antiokhius akan bertepatan dengan kemenangan Mikhael ${ }^{46}$ dalam peperangan surgawi. Collins menganggap malaikat Mikhael adalah "pemimpin" yang bertanggung jawab atas bangsa Yahudi, maka

${ }^{44}$ Newell, Tafsiran Kitab Daniel, 289.

${ }^{45}$ Willem A. Vangemeren, Penginterpretasian Kitab Para Nabi (Surabaya: Momentum, 2007), 379.

46Mikhael yang dimaksud di sini adalah gambaran dari kekuasaan Allah. Di mana Allah sebagai pemilik bangsa Israel membebaskan mereka dari belenggu penguasa lalim yang sudah menindas orang-orang Israel dengan sangat kejam. Pemerintahan yang lalim adalah merujuk kepada pemerintahan Antiokhus Epinanes IV. 
kemenangannya juga adalah kemenangan orang-orang Yahudi. ${ }^{47}$ Pada saat itu bangsa Israel atau orang-orang Yahudi akan dibebaskan, akan tetapi hanya orang-orang yang namanya ditemukan tertera dalam kitab. Menurut Newell, kitab yang dimaksud adalah Kitab Kehidupan berisi tulisan namanama orang yang benar, yakni orang-orang yang takut akan Tuhan dan menghormati nama-Nya. ${ }^{48}$

Jadi, menurut Dan.12, kematian bukanlah masa akhir dari segalanya. Kematian merupakan awal dari hal yang akan datang. Awal dari ketentuan hidup seseorang. Manusia yang telah mati, yang telah menjadi debu, bukanlah menjadi suatu masalah dalam kebangkitan. Dikatakan bahwa debu akan bangkit, jadi manusia yang telah menjadi debupun akan dibangkitkan dan tetap dapat dibangkitkan. Setiap manusia akan dibangkitkan oleh Allah. Seorang yang percaya dan taat kepada Allah, akan dibangkitkan untuk mendapatkan hidup kekal. Hidup bersama dengan Allah di kerajaan-Nya. ${ }^{49}$

Adanya gagasan tentang kebangkitan orang mati dalam kitab Daniel memberikan alasan mengapa maskulin atau para guru yang bijaksana bersedia mengorbankan hidupnya dalam perlawanan tanpa kekerasan. Sebagaimana kekuatan-kekuatan yang terlihat dalam pertempuran antara Antiokhus dan orang-orang Yahudi bukan hanya kekuatan yang tampak, demikian juga taruhan dalam peperangan itu tidak terdapat di dunia ini. Bagi orang-orang bijaksana, tujuan hidup ialah agar disucikan sebagaimana semestinya dan menjadi selaras dengan dunia para malaikat, dengan maksud untuk menikmati persekutuan kekal bersama malaikat atau di kehidupan surga. ${ }^{50}$ Orang-orang bijaksana ini ialah orang-orang yang sangat setia kepada Allah, dan berjalan dalam kebenaran-Nya, sehingga orang-orang bijaksana dapat

${ }^{47}$ Collins, Tafsir Deutoronika 4, 79.

${ }^{48}$ Newell, Tafsiran Kitab Daniel, 346.

${ }^{49}$ Kebangkitan yang dimaksud adalah tujuan utamanya bukan merujuk kepada kebangkitan orang mati secara harafiah, tetapi tujuannya untuk memperjuangkan kebenaran itu membutuhkan pengorbanan, termasuk nyawa sekalipun.

${ }^{50}$ Collins, Tafsir Deutoronika 4, 80. 
menuntun orang lain agar mengerti surga Allah, mengenal Dia, dan berjalan dalam kebenaran-Nya (Lihat uraian Dan.11:32-33). ${ }^{51}$

Daniel pasal 12 adalah salah satu bagian yang mengungkapkan secara tegas harapan terhadap pahala sesudah kematian, diungkapkan dalam "tubuh yang dibangkitkan." Orang yang mati syahid akan dibangkitkan untuk mewarisi kerajaan, dan orang jahat akan menerima pahalanya dengan adil.52 Ada beberapa bagian dalam Perjanjian Lama yang menyinggung kehidupan setelah kematian, khususnya Yesaya 26:19 (orang-orang-Mu yang mati akan bidup pula, mayat-mayatnya akan bangkit pula).

Daniel 12 bukanlah ungkapan kepercayaan yang paling awal dari orangorang Yahudi tentang kebangkitan, karena sebelumnya sudah ditemukan dalam kitab-kitab yang memuat unsur apokaliptik. Namun Daniel memberikan penjelasan yang baik mengenai fungsi keyakinan itu dan tentang cara keyakinan itu muncul. Jelas tidak ada soal pembuktian secara objektif. Kebangkitan merupakan bagian terpadu dari pewahyuan apokaliptik. ${ }^{53}$ Yang menjadi dasar dari keyakinan itu ialah bahwa pewahyuan itu disampaikan melalui wibawa malaikat dan hanya dapat diterima atau ditolak. Kepercayaan akan kebangkitan dalam Daniel merupakan dasar pendirian para martir. Harapan itulah yang memungkinkan umat Tuhan lebih suka mengorbankan hidupnya daripada tunduk pada tuntutan penguasa dunia yang jahat. ${ }^{54}$

Jadi, harapan akan adanya kebangkitan setelah kematian dalam kitab Daniel merupakan dasar pendirian para martir dalam agama Yahudi. Harapan itulah yang memungkinkan umat Tuhan lebih suka mengorbankan hidupnya daripada tunduk pada tuntutan penguasa dunia yang jahat. Umat Tuhan yang mati syahid akan dibangkitkan untuk mewarisi kerajaan Allah di dalam hidup yang kekal, dan orang jahat akan menerima penghukuman selamanya. Ketika semua orang yang mati dibangkitkan maka hal ini berhubungan dengan penghakiman yang akan berlangsung untuk semua orang, ketika Tuhan datang. Penghakiman ini digambarkan suatu pengadilan agung di saat Allah akan duduk di atas takhta-Nya dan menjatuhkan keputusan-Nya atas semua umat manusia. Orang-orang yang tidak

${ }^{51}$ Newell, Tafsiran Kitab Daniel, 349.

${ }^{52}$ Russel, Penyingkapan Ilahi, 132.

${ }^{53}$ Newell, Tafsiran Kitab Daniel, 81-82.

54Ibid, 82. 
mengenal Allah beserta si jahat akan dilenyapkan selamanya, sedangkan umat Tuhan akan mendapat hidup kekal (Dan.7:36) bersama dengan Tuhan, di mana ada sukacita dan kedamaian.

\section{Bersifat Tersembunyi}

Waktu eskatologi tidak ada yang dapat mengetahui, Daniel pun yang mendapatkan penglihatan tidak dapat mengetahuinya. Tidak ada satupun manusia yang dapat mengetahui. Pada saat ini ada beberapa orang yang berusaha menafsirkan dan mencari tahu waktu yang sebenarnya mengenai akhir zaman. Namun sampai sekarang tidak pernah dapat menemukannya. Ada yang menafsirkan tanggal, dan waktunya, namun tidak pernah terjadi. Bahkan Daniel pun menjelaskan ketidaktahuanya di dalam pasal 12.

Jadi Dan 12 merupakan sebuah nubuat paling akhir dari kitab ini, juga adalah kata penutup bagi keseluruhan kitab. Dalam Dan 12:5 dikatakan Malaikat sekali lagi membawa Daniel ke tepi sungai. Salah satu dari antara dua orang malaikat mengajukan pertanyaan yang krusial penting bagi Daniel dan umat yang ditawan: Bilakah hal-hal yang ajaib ini akan berakhir? (Dan 12:6). Dalam masa kesusahan besar, masih harus menunggu berapa lama, kesulitan baru akan berlalu?

Malaikat yang ada di seberang tepi sungai menjawab: Satu masa dan dua masa dan setengah masa; dan setelah berakhir kuasa perusak bangsa yang kudus itu, maka segala hal ini akan digenapi! Satu masa dan dua masa dan setengah masa. Bagian ini sejajar dengan pasal 7 yang menyebutkan umat kudus akan menerima aniaya dari tanduk kecil selama satu masa dan dua masa dan setengah masa (Dan 7:25). Malaikat tidak memberikan sebuah tanggal yang konkrit, namun memberikan petunjuk bahwa saat akhir zaman muncul, dan setelah hari akhir barulah hal-hal itu keseluruhannya akan digenapi (Dan 12:7). ${ }^{55}$

Teks sebelumnya menyatakan akhir dari umat yang setia beriman dan yang durhaka akan sama sekali berbeda, yang setia mendapatkan hidup

55 Siahaan, Tafsiran Alkitab: Kitab Daniel, 23. 
kekal, yang durhaka menerima kengerian selamanya. Perhentian akhir mereka, sesungguhnya diputuskan berdasarkan kehidupan iman mereka di atas bumi. Orang benar akan bertekun, menjaga kesucian, bersabar menerima tempaan (disucikan dan dimurnikan dan diuji), karena memahami kehendak dan rencana Allah; Orang fasik justru menuruti nafsu menjalankan kejahatan (Dan 12:10). Kitab Daniel menggabungkan karakteristik dari sastra hikmat dan sastra apokaliptik, mendorong pembaca bersemangat menjadi orang bijak/berhikmat, yakni bersandar kepada Allah, waspada menuruti dan menjalankan perintah-Nya; Malaikat juga memberikan sebuah pandangan kekal yang melampaui zaman: Allah adalah Tuhan pemegang kendali sejarah, Dia adalah yang awal, dan yang akhir, Dia dalam kekekalan telah menetapkan rencana, juga pasti menggenapkannya.

Saat Daniel mengejar lagi dalam pertanyaan, Malaikat memberi dua petunjuk menyangkut waktu: seribu dua ratus dan sembilan puluh hari (1200 + 90 hari) merujuk kepada waktu penyucian Bait Suci ${ }^{56}$, dan seribu tiga ratus tiga puluh lima hari (1335 hari) (Dan 12:11-12). Seribu dua ratus dan sembilan puluh hari, setengah tujuh masa (Dan 9:27), dan satu masa dan dua masa dan setengah masa (Dan 12:7) ketiganya adalah satu jenis yang sama, semuanya menunjuk masa waktu umat Allah menerima siksaan dari penguasa yang lalim. Selama masa menderita, umat kudus harus bersabar menantikan datangnya Kerajaan Allah, setelah genap menanti seribu dua ratus dan sembilan puluh hari $(1200+90$ hari) tetap belum cukup, justru hendak menunggu sampai genap seribu tiga ratus tiga puluh lima hari (1335 hari).

Jadi, malaikat tidak memberi perintah kepada Daniel untuk menghitung tanggal konkritnya, hanya berpesan: "Tetapi engkau, pergilah sampai tiba akhir zaman, dan engkau akan beristirahat, dan akan bangkit untuk mendapat bagianmu pada kesudahan zaman" (Dan. 12:13). Dasar dari perhitungan yang misterius adalah iman yang tegas, yang tidak dapat dipadamkan, tidak dapat dibinasakan oleh kesulitan dan penganiayaa. Iman merupakan hal yang penting dan benarm apakah penghitungan jumlah harihari dalam Daniel tepat ataukah tidak. Daniel yang sudah lanjut usia, telah mengalami pergantian dinasti, telah mengakhiri pertempuran yang baik,

56 Ibid, 204. 
telah mencapai garis akhir dari jalan yang harus di lalui, telah memelihara iman, dapat dengan tenang menantikan bagian yang disimpan baginya.

\section{Kedatangan Zaman Keselamatan}

Dalam membaca sastra apokaliptik, maka para pembaca dapat menemukan pembedaan yang tegas antara dunia yang sekarang dengan dunia yang akan datang. Sastra apokaliptik berbicara mengenai eskatologi, yaitu akhir dunia yang semakin memburuk sampai benar-benar kiamat, lalu tiba-tiba muncul dunia baru yang serba indah. Saat dunia yang baru itu datang, segala kejahatan dan kuasanya akan dimusnahkan oleh Allah, orangorang yang telah mati akan dibangkitkan, dan akan ada penghakiman bagi semua orang. Dalam pandangan apokaliptik, bumi dilihat secara menyeluruh dan tidak hanya terbatas pada umat Israel. Apokaliptik juga tidak hanya berbicara melampaui batas sejarah sampai ke eskatologi, tetapi juga protologi yaitu keadaan sebelum dunia diciptakan. Pola pikir dualistis seperti membedakan antara zaman sekarang dan akan datang, antara bumi dan surga, antara orang suci dan orang jahat sangat menonjol dalam sastra apokaliptik. Dengan datangnya dunia yang baru maka berakhirlah penderitaan orang-orang percaya yang tertindas. Sastra apokaliptik dengan demikian mendorong orang-orang agar dapat bertahan dalam penindasan. Sasaran akhir tulisan ini adalah berakhirnya segala kejahatan, kekuasaan yang dimiliki negara-negara besar di dunia tidak akan bertahan lama, dan zaman keselamatan pun tiba. ${ }^{57}$

\section{MAKNA ESKATOLOGI DANIEL}

Pada dasarnya PL tidak sedikit membicarakan eskatologi yang berhubungan dengan iman yang akan datang. Salah satu aspek Perjanjian Lama yang paling penting adalah pengharapan terhadap masa yang akan datang (eskaton). Eskaton dipahami sebagai hal yang terakhir. Konsep

${ }^{57}$ Y.M Seto Marsunu, Apokaliptik : Kumpulan Karangan Simposium Ikatan Sarjana Biblika Indonesia2006 (Jakarta: Lembaga Alkitab Indonesia, 2007), 10-18. 
Eskaton dalam PL juga dipahami sebagai akhir zaman (Yes.65:17; 66:23) dan adanya suatu langit dan bumi yang baru (Yes.65:17, 66:23). Pada umumnya pengharapan di Perjanjian Lama merupakan pandangan yang optimis tentang masa depan yang mengharapkan berkat jasmani dan rohani serta perubahan dalam kehidupan politik dan adanya harapan bahwa akan terjadi suatu perubahan yang radikal yang dilakukan oleh Allah kelak. ${ }^{58}$ Adapun harapan Eskatologi dalam Perjanjian Lama didasarkan pada :

1. Keyakinan bahwa Allah tetap berkarya, walaupun kehidupan bisa saja sulit.

2. Ketegangan antara kehadiran Allah dan ketersembunyian-Nya yang menimbulkan pengharapan akan kehadiran Allah secara sempurna pada masa depan.

3. Keyakinan para nabi bahwa Allah akan berkarya pada masa depan sebagaimana Ia berkarya pada masa lalu walaupun dengan cara yang benar-benar baru.

Sejak awal zaman para nabi memiliki keyakinan akan ada waktu atau hari ketika Tuhan Allah akan campur tangan dalam sejarah Israel (Amos 5:18-20) keyakinan ini nyata dalam ungkapan 'Hari Tuhan' (Yes.13:6,9; Yeh.13:5, Y1.1:15,2:1,11,35, Ob.15, Zef.1:7,14, Za.14:1).

Akhir zaman dalam kitab Daniel digambarkan sebagai tindakan Allah yang menyelamatkan umat Israel dari kekuasaan raja yang lalim dan bahwa Allah sungguh-sungguh memegang kendali atas semua yang terjadi di dunia ini. ${ }^{59}$ Pemerintah-pemerintah lalim dapat saja berkuasa, tetapi itu bisa terjadi dengan seizin Allah saja. Kebangkitan dan keruntuhan para pemerintah sudah diketahui sebelumnya dan telah ditakdirkan oleh Allah. Tetapi kendatipun demikian halnya, para pemerintah tidak dapat begitu saja dibebaskan, sebab setiap pemerintahan lalim pada waktu yang sama harus memikul tanggung jawab atas segala kejahatan yang dilakukannya dan akan diadili. ${ }^{60}$ Pengadilan itu juga telah ditetapkan sebelumnya - bukan hanya

${ }^{58}$ David L. Baker, Satu Alkitab Dua Perjanjian (Jakarta : BPK Gunung Mulia, 2001), 23.

${ }^{59}$ Collins, Tafsir Deutoronika 4, 83.

${ }^{60}$ Newell, Tafsiran Kitab Daniel, 343. 
pengadilan terhadap kerajaan-kerajaan dan penguasa-penguasanya, tetapi juga atas semua orang atau orang perorangan. ${ }^{61}$

Para penulis apokaliptik merupakan orang-orang yang bijaksana, mereka dapat menafsirkan kejadian-kejadian di dalam sejarah dari sudut kekekalan dan mampu melihat makna dan penghakiman di dalam sejarah, karena pada akhir dari semuanya yang sedang berlangsung terletak tujuan dari semuanya itu yang telah ditakdirkan dan ditentukan sebelumnya oleh Allah, yang dari sudut-Nya seluruh sejarah akhirnya menjadi berarti. Arti yang sebenar-benarnya dari sejarah bagi para penulis apokaliptik terletak pada akhirnya, pada penyempurnaannya, pada pemenuhannya di dalam kedatangan Kerajaan Allah.

Jadi, kitab Daniel berisi pesan pengharapan yaitu bahwa umat Tuhan harus beriman, meskipun segala hal kelihatannya bertentangan dengan kepercayaan, namun haruslah tetap percaya bahwa Allah sungguh-sungguh memegang kendali atas semuanya. Pemerintah-pemerintah lalim dibawah kuasa Iblis mungkin dapat berkuasa untuk sementara, tetapi itu bisa terjadi dengan seizin Allah saja. Kebangkitan dan keruntuhan para pemerintah dunia yang jahat sudah diketahui sebelumnya dan telah ditakdirkan oleh Allah. Tetapi kendatipun demikian, para pemerintah tidak dapat begitu saja dibebaskan, sebab setiap pemerintahan lalim pada waktu yang sama harus memikul tanggung jawab atas segala kejahatan yang dilakukannya dan akan diadili.

\section{KESIMPULAN}

Penggunaan kata "akhir zaman" di dalam Dan.12:1-13 memakai kata yang sama yaitu "eth/ "עי " untuk waktu dan "qets/ r??" untuk akhir. Hal tersebut merujuk kepada berakhirnya suatu periode. Jika melihat kitab Daniel secara keseluruhan, maka akan terlihat adanya penekanan khusus mengenai hubungan dari sejarah manusia, yaitu mengenai akhir zaman.

Dalam pasal 12:1-13, penekanan pada masa akhir sejalan dengan fokus dari sejarah manusia. Oleh karena itu, penekanan 'akhir zaman' tidak hanya dirancang untuk membuat seseorang sadar akan pentingnya akhir zaman,

${ }^{61} \mathrm{Ibid}, 348$. 
tetapi juga untuk menggaris-bawahi realitas sejarah. Akhir zaman bukanlah konsep teologis yang samar-samar, atau, sebagaimana sebagian orang menyatakan, pemikiran yang tenang dibentuk oleh orang yang menderita. Masa akhir diatur dalam kitab Daniel dalam realitas sejarah manusia. Memang benar bahwa hal ini didorong oleh visi ini melebih beberapa abad, para nabi berani untuk menempatkan masa akhir yang berkaitan dengan seluruh sejarah dunia, dan bahkan lebih jauh sampai pada tahap terakhir.

Berdasarkan tafsiran dari beberapa para ahli teologi mengenai Dan.12, terdapat dua kubu dalam memandang akhir zaman yang dimaksudkan dalam Dan.12, yaitu pertama kubu yang menerima bahwa akhir zaman merupakan peristiwa yang terjadi pada masa itu dengan ditandai berakhirnya kekuasaan penguasa yang lalim yaitu Antiokhus Efipanes IV. Mereka mendasari pandangannya dari peristiwa sejarah yang terjadi di dalam kitab Daniel. kedua, kubu yang menolak bahwa akhir zaman bukan hanya berbicara mengenai berakhirnya kekuasaan Epifanes IV, tetapi akhir zaman berbicara mengenai masa itu, dan masa yang akan datang. Kubu ini, berpandangan demikian karena yang menjadi dasarnya adalah dalam memahami kitab Daniel tidak bisa hanya dilihat dari segi sejarahnya saja, tetapi harus dilihat dari segi futurisnya juga.

Jadi menurut penulis, akhir zaman yang dimaksud dalam Kitab Daniel merupakan hal mengenai eskatologi. Zaman itu akan disebut zaman kesesakan. Kesesakan dan penderitaan tersebut akan dialami oleh orangorang Israel atau umat Tuhan. Secara khusus penderitaan yang disebabkan oleh penindasan dari penguasa yang jahat. Kekuasaan raja yang lalim itu merujuk kepada pemerintahan Antiokhus Epifanes IV, tetapi penindasannya tidak akan berlangsung selamanya karena Allah akan menggulingkan atau mengalahkan Antiokhus Epifanes IV. Kekalahan atau berakhirnya kekuasaan Efipanes IV merupakan pengertian dari akhir zaman menurut kitab Daniel. Makna dari akhir zaman dalam kitab Daniel yaitu, untuk mengajarkan supaya umat Allah tetap bertahan di dalam mempertahankan iman mereka kepada Allah, dan tetap setia kepada Allah selamanya.

Robi Prianto adalah dosen STT SAPPI yang menyelesaikan program S1 (S.Th.) di STT SAPPI dan Program S2 (M.Th.) dari STT Cipanas. 